\title{
EXPANDING TO THE EDGES: CENTRAL NUMIC DUAL NUMBER ${ }^{1}$
}

\author{
John E. McLaughlin \\ Utah State UnIVERSiTy
}

\begin{abstract}
The Central Numic (Uto-Aztecan) dual number marking system on nouns and pronouns is of interest because even though most of the component morphemes involved in the system are reconstructible to Proto-Numic, the system itself is not. Indeed, while the reconstructible Proto-Numic system is rudimentary, the Central Numic system is robust and has expanded to the point that there are few environments where dual is not marked on equal footing with singular and plural. The Central Numic system is of further interest because it involves cycles of grammaticalization and not just a single diachronic event. This contrasts with the other two branches of Numic, Western and Southern, where the very rudimentary Proto-Numic dual number has been maintained and only minimally expanded. The tarpaper shack of Proto-Numic dual marking is now the steel-and-glass high-rise of Central Numic dual marking.
\end{abstract}

[KeYwords: Uto-Aztecan languages, dual number, grammaticalization, Central Numic]

1. Introduction. This paper traces the expansion of distinct dual number syntax and morphology in the Central Numic languages of Uto-Aztecan (Timbisha [par], Shoshoni [shh], and Comanche [com]). Although there is no reconstructible dual in Proto-Uto-Aztecan, Proto-Numic had a distinct form for the first person inclusive dual pronoun. While the Southern Numic and Western Numic languages have hardly more evidence of a distinct dual than this, the Central Numic languages have innovated entire dual pronominal and nominal paradigms beginning in Proto-Central Numic, as well as a range of distinctive dual verb forms. The languages used common grammaticalization resources to create these dual forms, including reduplication

\footnotetext{
${ }^{1}$ My interest in Central Numic dual number marking has its origin in a conversational comment made by Wick R. Miller about the apparent similarity of dual subjective suffixes between Comanche and Timbisha and the dissimilarity of the same suffix in Shoshoni. Although my analysis comes to a different conclusion than his very preliminary suggestion, Wick's influence on the field of Central Numic studies can never be overstated. Various sections of this paper have benefitted from presentation and discussion at conferences including the 2012 Workshop in General Linguistics (University of Wisconsin-Madison), the 2012 Conference on Endangered Languages and Cultures of Native America (University of Utah), the 2013 Society for the Study of the Indigenous Languages of the Americas annual meeting (Boston), and the 2013 Friends of Uto-Aztecan Conference (Boise State University). The anonymous IJAL reviewers and associate editor also provided useful feedback and suggestions. All errors of description and interpretation, however, lay squarely at the feet of this author.
}

[IJAL, vol. 84, no. 3, July 2018 , pp. 359-81]

(C) 2018 by The University of Chicago. All rights reserved.

0020-7071/2018/8403-0003\$10.00 DOI 10.1086/697587 
of the singular root and grammaticalization of *waha 'two' (on not just one, but two separate occasions). This innovation and expansion of distinct dual number marking in Central Numic is interesting not only in the thoroughness of its expansion throughout the nominal, pronominal, and verbal paradigms, but also in the relatively short time in which it occurred.

2. The Numic Languages of Uto-Aztecan. The seven generally recognized Numic languages are divided into three well-defined subgroups as shown in (1).

(1) Numic

Western Numic: Northern Paiute [pao], Mono [mnr]

Southern Numic: Colorado River [ute], Kawaiisu [xaw]

Central Numic: $\quad$ Shoshoni, Comanche, Timbisha

Of the three Central Numic languages, Timbisha was spoken in the desert valleys from Owens Lake, California, to Death Valley; Shoshoni was spoken over an area from southwestern Nevada to Utah, southern Idaho, and central Wyoming; and Comanche was spoken on the western margin of the Great Plains from the Arkansas River to the Rio Grande. Timbisha and Shoshoni are now spoken only in discontinuous pockets throughout their former ranges, and Comanche is isolated in a small area of southwestern Oklahoma. Historically, Comanche is an offshoot of the easternmost Shoshoni dialect, separating possibly as late as the early eighteenth century. The division between Timbisha and Shoshoni is much older, probably between one and two millennia ago.

3. Number in Uto-Aztecan. Langacker (1977:80) reconstructed only an unmarked singular and a marked plural for Proto-Uto-Aztecan. He noted that only the Numic languages along with neighboring Hopi [hop] and Tübatulabal [tub] have innovated a dual number. The three systems are not reconstructible to a common ancestor, however. The Hopi nominal dual is shown in (2). ${ }^{2}$ Dual is marked almost exclusively on animates, ${ }^{3}$ inanimates

\footnotetext{
2 Transcription throughout the paper generally follows Uto-Aztecan and Americanist practice with the following to be noted: $y=\operatorname{IPA} j$, ' (apostrophe) $=$ IPA $f, r=$ IPA $\ldots$, long vowels are written double, and voiceless vowels and sonorants are capitalized. Abbreviations are PN (Proto-Numic), PCN (Proto-Central Numic), Tm (Timbisha), Sh (Shoshoni), Cm (Comanche), NP (Northern Paiute), Kw (Kawaiisu), CR (Colorado River); 1, first person; 2, second person; 3, third person; ABS, absolutive; COREF, coreferential; DEM, demonstrative; DIM, diminutive; DL, dual; DUR, durative; EXCL, exclusive; INCL, inclusive; INDEF, indefinite; INTR, intransitive; OBJ, object[ive]; PL, plural; POSS, possessive; PRES, present; RDP, reduplication; REFL, reflexive; REM, remote; SBJ, subject[ive]; sG, singular; sUB, subordinate clause; TR, transitive; Fa (father), Mo (mother), Br (brother), Si (sister), Ol (older), Yo (younger).

3 The term "animate" in the languages represented here generally refers to the semantic class of those things which are alive and capable of movement. Thus, a squirrel is generally animate whereas a tree is not. Sentience, such as the Sun personified, can also impart animacy
} 
that seem to move of their own accord (such as clouds), and sacred things. The dual is marked with a suffix $-t$ on the singular stem. Hopi treats dual as plural otherwise (Jeanne 1978:72ff.; HDP 1998:870). ${ }^{4}$

(2) Hopi

$\begin{array}{lll}\text { maana } & \text { maana-t5 } & \text { ma-mant } \\ \text { girl } & \text { girl-DL } & \text { RDP-girl.PL } \\ \text { 'girl' } & \text { 'two girls' } & \text { 'girls' }\end{array}$

(Jeanne 1978:73)

$\begin{array}{lll}\text { sino } & \text { sino-t } & \text { sino-m } \\ \text { person } & \text { person-DL } & \text { person-PL } \\ \text { 'person' } & \text { 'two persons' } & \text { 'persons' }\end{array}$

(HDP 1998:870)

There is also a syntactic expression of dual number. Dual subjects of suppletive verbs take the singular form of suppletive verbs as in (3) and (4).

(3) Hopi

mi' maana paki

DEM.REM.SG.SBJ girl enter.SG

'That girl entered.'

mima maana-t paki

DEM.REM.PL.SBJ girl-DL enter.SG

'Those (two) girls entered.'

mima ma-mant yungya

DEM.REM.PL.SBJ RDP-girl.PL enter.PL

'Those (several) girls entered.'

(Jeanne 1978:73)

(4) Hopi

$\mathrm{Nu}$ kawayo-t tuwa

1sG.SBJ horse-OBJ see

'I saw a horse.'

Itam kawayo-t tuwa

1PL.SBJ horse-OBJ see

'We (two) saw a horse.'

to normally inanimate objects in specific contexts, such as in a Coyote story. In Hopi, the term "animate," while maintaining this semantic basis, also denotes the formal morphological class which defines how plural is marked on nominals.

${ }^{4}$ Examples from Jeanne 1978 have been respelled to match the orthography in the Hopi Dictionary Project (HDP).

5 HDP 1998:218 lists mànt as a variant form for 'two girls'. 
TABLE 1

Tübatulabal Independent Pronouns and Pronominal Affixes

\begin{tabular}{lllll}
\hline \hline & Independent & Conjunctive & Object & Possessive \\
\hline 1DL.INCL & ingila & -gila & $-a$ & \\
1DL.EXCL & ingila'an & -gila'a & -džiya'an & -tš \\
\hline
\end{tabular}

Source: Voegelin 1935:135, 137

${ }^{a}$ The absence of object and possessive forms for dual inclusive is unexplained in Voegelin (1935). It is perhaps a gap in the data.

TABLE 2

Western Numic and Southern Numic Pronouns

\begin{tabular}{lllll}
\hline \hline & SG & DL & PL INCL & PL EXCL \\
\hline Western Numic & & & & \\
\hline Northern Paiute & ni & ta & tammi & nimmi \\
Mono & nii & taa & taakkwa & nïkkwa \\
Southern Numic & & & & \\
\hline Kawaiisu & ni’ ${ }^{\prime}$ & tami & tawa & nimi \\
Colorado River & nił & tammi & tami & nimmi \\
\hline
\end{tabular}

$$
\begin{aligned}
& \text { Itam kawayo-t } \quad \text { tu-twa } \\
& \text { 1PL.SBJ horse-OBJ } \\
& \text { 'WDP-see } \\
& \text { (several) saw a horse.' }
\end{aligned}
$$

(HDP 1998:870)

Tübatulabal has innovated a set of dual pronouns and pronominal affixes used only with first person (Voegelin 1935:134ff.). These are shown in table 1. The -gildži part of the forms marks non-singular. There is no dual morphology on nominals. ${ }^{6}$

Thus, there is no relationship between the Hopi dual system, which is not pronominal, and the Tübatulabal system, which is pronominal and restricted to first person.

4. Number in Western and Southern Numic. For the category of dual in the Western and Southern Numic languages, we are still looking at a restricted category of pronouns and pronominal affixes. In both of these Numic branches, a dual first person pronoun has been developed as shown in table 2 , which illustrates the first person pronouns in subjective case. ${ }^{7}$

6 Tübatulabal forms from Voegelin (1935) have been respelled to reflect contemporary practice.

7 The Southern and Western Numic grammar descriptions and examples are from Snapp et al. 1982 (Northern Paiute), Thornes 2003 (Northern Paiute), Norris 1986 (Mono), Zigmond 
These forms are especially relevant for Proto-Numic since Western Numic and Southern Numic are noncontiguous branches of Numic, separated by Central Numic. Based on this evidence, dual pronouns in Proto-Numic were formed from the plural inclusive stem. The plural inclusive form is itself reconstructible to Proto-Uto-Aztecan as the first person plural pronoun * $(i$ - $)$ $t a(-m \dot{t})$ (Langacker 1977:124). The special relationship between inclusive and dual is well-documented in the world's languages, whereas a special relationship between dual and exclusive is extremely rare (Cysouw 2013). This is clearly evident in the Western Numic forms, where the unmarked stem is dual, and plural is formed with the addition of a plural suffix. This represents the majority of information concerning pronominal dual in the non-Central Numic languages. There is no nominal dual marking in any of these languages.

Syntactically, non-first-person dual subject is marked in Southern Numic (in both Kawaiisu and Colorado River) by combining a plural pronoun or pronominal affix with the singular form of a suppletive verb, as in (5), or a verb without a plural suffix, as in (6).

(5) Colorado River qari-yi-ana

sit.SG-PRES-3SG

'he sits'

qari-yi-ami

sit.SG-PRES-3PL

'they (two) sit'

yurwi-yi-ami

sit.PL-PRES-3PL

'they sit'

(Sapir 1930:160)

(6) Colorado River

ivi-yi-ni

drink-PRES-1SG

'I drink'

ivi-yi-nimwi

drink-PRES-1PL.EXCL

'We (two, exclusive) drink'

et al. 1991 (Kawaiisu), Sapir 1930 (Colorado River), Press 1980 (Colorado River), and Givón 2011 (Colorado River). Page numbers from Sapir (1930) in this paper refer to the original 1930 pagination, which is retained in the 1992 reprinted text alongside the new page numbering. 
TABLE 3

Sample Suppletive Verbs in Numic

\begin{tabular}{|c|c|c|c|c|c|c|}
\hline & & Mono & NP & $\mathrm{Tm}$ & $\mathrm{Sh}$ & $\mathrm{CR}$ \\
\hline \multirow[t]{3}{*}{ 'sit' } & SG & katti & katti & kati & kati & kadi \\
\hline & $\mathrm{DL}$ & yikkwi & yigwi & kati, yikwi & yikwi & kadi \\
\hline & $\mathrm{PL}$ & yikkwi & aatta'a & nuupai, yuunaa & yikwi & yurwi \\
\hline \multirow[t]{3}{*}{ 'stand' } & SG & wini & wini & wini & wini & winni \\
\hline & $\mathrm{DL}$ & kono & wami & wiwini & tsatsakki & winni \\
\hline & PL & kono & kono & toppani, tattsaho & topo'i & wanwi \\
\hline \multirow[t]{3}{*}{ 'lie’ } & SG & habi & happi & hapi & hapi & avi \\
\hline & DL & kwabi & kwappi & kwopi, kopi & kwapi & avi \\
\hline & $\mathrm{PL}$ & kwabi & pokkwa & kopi-ttiki & kwapi & kwavi \\
\hline
\end{tabular}

Source: Babel et al. 2013:472

ivi-kka-yi-nimwi

drink-PL-PRES-1PL.EXCL

'We (exclusive) drink'

(Sapir 1930:160)

Northern Paiute has developed dual suppletive forms for a small number of intransitive verbs and reduplicates the first syllable of many other common verbs to mark dual. Other than pronouns, Mono has no other dual marking, indicating that the dual verb forms in Northern Paiute are probably the result of feature borrowing from neighboring Shoshoni (Babel et al. 2013:472). Table 3 illustrates three suppletive positional verbs in Numic, showing the lack of dual forms in Mono and Southern Numic (represented by Colorado River) and the presence of dual forms in Northern Paiute and Central Numic.

Thus, outside Central Numic, there is a limited set of first-person dual pronouns based on the plural inclusive pronominal stem (reconstructible to Proto-Numic), syntactic marking of dual in Southern Numic (reconstructible to Proto-Southern Numic and probably borrowed into Hopi as in 3 and 4), and some suppletive marking of dual in common verb stems in Northern Paiute (borrowed as a feature from Shoshoni).

5. Number in Timbisha. Central Numic has taken dual to several levels of complexity beyond what is found in the other Numic branches. Central Numic's system, although not reconstructible to Proto-Numic, illustrates what can happen when a grammaticalization process runs amok and expands a feature well beyond its original restricted occurrence. Dual marking in Central Numic has expanded beyond first person in pronouns to include pronouns in all persons, nouns, adjectives, verbs, demonstratives, and the number two, which takes the set of dual adjectival suffixes. 
The Timbisha system is typical of Central Numic systems, so it will be described first in more detail, beginning with nominal affixation and then proceeding to pronominal, demonstrative, and other affixation, and concluding with number suppletion in verbs. ${ }^{8}$

Number affixation on nouns is generally optional in Central Numic. In (7), the two sentences mean the same thing. The second sentence has a noun marked for plural with reduplication; the first does not. The number of the subject in both sentences is indicated by the plural suppletive form of the verb, which is required.

(7) Timbisha

$\begin{array}{lllll}\text { tajummi } & \text { najkaha } & \text { nii } & \text { naajkan } & \text { nijwinni } \\ \text { tayummi-i } & \text { nayka-han } & \text { nï } & \text { naajkan } & \text { nigwinni } \\ \text { man-OBJ } & \text { hear-SUB } & \text { I } & \text { make.noise } & \text { talk.PL.SBJ }\end{array}$

'I hear the men (who are) making noise talking.' 9

(Dayley 1989a:216)

$\begin{array}{lllll}\text { tattayummi } & \text { najkaha } & \text { nii } & \text { naajkan } & \text { ninwinni } \\ \text { tat-tanummi-i } & \text { nayka-han } & \text { nï } & \text { naajkan } & \text { ninwinni } \\ \text { RDP-man-OBJ } & \text { hear-SUB } & \text { I } & \text { make.noise } & \text { talk.PL.SBJ }\end{array}$

'I hear the men (who are) making noise talking.'

(Dayley 1989a:222)

Number marking on nominals is done with reduplication, suffixation, or both depending on the noun. There is much dialectal and idiolectal variation in the forms in both Timbisha and Shoshoni. Examples are shown in table 4.

The number suffixes on nominals are shown in (8) and illustrated in (9).

${ }^{8}$ The Timbisha grammar descriptions are from Dayley 1989a and McLaughlin 2006. Some data are from Wick R. Miller's fieldnotes. Throughout Central Numic, both progressive and regressive vowel assimilation in unstressed syllables are common. It will not generally be remarked upon except where necessary for clarity.

${ }^{9}$ The gloss is Dayley's. An anonymous reviewer notes, however, that the verb 'hear' is marked as subordinate and suggests the alternate translation, 'The men whom I hear are making noise talking'. The two translations each have their strengths. Dayley's translation emphasizes the objective marking on tayummi 'man' and the main clause long vowel of $n \ddot{t} \dot{t}$ ' $\mathrm{I}$ '; the alternate translation emphasizes the subordinate marking on naajka 'hear'. A similar sentence (Dayley 1989b:128) adds a main clause subject demonstrative referring to the object of the subordinate clause and uses the subordinate clause short vowel of $n \dot{t}$ 'I'.

(i) Timbisha

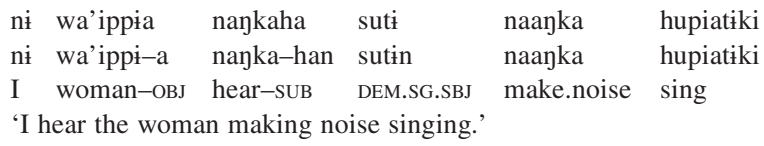

This sentence is more literally, 'The woman I hear, she is making noise singing.' 
TABLE 4

Timbisha Nominal Number Marking

\begin{tabular}{|c|c|c|c|}
\hline & SG & DL & PL \\
\hline \multicolumn{4}{|l|}{ Suffixes only } \\
\hline grandfather $(\mathrm{FaFa})$ & kinu & kinu-anku & kinu-ammi \\
\hline grandmother (FaMo) & huttsi & huttsi-ajku & huttsi-ammi \\
\hline antelope & wantsi & wantsi-ạku & wantsi-ammi \\
\hline young woman & naittsi & naittsi-ahu & naittsi-ammi \\
\hline \multicolumn{4}{|l|}{ Reduplication only } \\
\hline duck & piyin & pip-piyin & piyin \\
\hline gun & eti & e'-eti & eti \\
\hline house & kahni & kak-kahni & kahni \\
\hline \multicolumn{4}{|c|}{ Suffixes and Reduplication } \\
\hline man & $\operatorname{tanwammi}^{a}$ & tat-tanwa- $\eta \mathrm{ku}$ & tat-tanwa-mmi \\
\hline bear & pahapittsih & pap-pahapittsih & pahapittsi-ammi \\
\hline pet & puyku & pup-punku & pup-punku-mmi \\
\hline mother & pia & pip-pia-hu & pip-pia-mmi \\
\hline
\end{tabular}

${ }^{a}$ The final -mmi is an unproductive nominal suffix found on a small number of noun stems, such as tanwammi 'man' and piammi 'infant'. It is dropped in the dual and plural but retained in the singular.

(8) Timbisha ${ }^{10}$

$\begin{array}{lll} & \text { DL } & \text { PL } \\ \text { SBJ } & \text {-ahu } \sim \text {-anku } \sim \text {-nku } \sim \text {-mujku } & \text {-ammi } \sim \text {-mmi } \\ \text { OBJ } & \text {-ahi } \sim \text {-hi } \sim \text {-muhi } \sim \text {-ankwi } & \text {-ammi } \sim \text {-mmi } \\ \text { POSS } & \text {-ahin } \sim \text {-hin } \sim \text {-muhin } \sim \text {-aykwin } & \text {-ammin } \sim \text {-mmin }\end{array}$

(9) Timbisha

$\begin{array}{lllll} & & \text { SG } & \text { DL } & \text { PL } \\ \text { 'great-grandparent' } & \text { SBJ } & \text { tso'o } & \text { tso'o-anku } & \text { tso'o-ammi } \\ & \text { OBJ } & \text { tso'o-a } & \text { tso'o-ahi } & \text { tso'o-ammi } \\ & \text { POSS } & \text { tso'o-an } & \text { tso'o-ahin } & \text { tso'o-ammin }\end{array}$

Since a first-person dual pronoun is reconstructible to Proto-Numic, we should expect to find a reflection of this in Central Numic and Timbisha. Unlike in Western and Southern Numic, however, where the dual forms are not completely integrated into the full pronominal paradigm, dual pronouns in Central Numic are fully integrated and form a complete paradigm with the other pronouns. The pronominal system in Timbisha consists of pronominal roots combined with the same number suffixes for dual and plural that are found on nominals, although with less variation. Table 5 illustrates the pronouns in Timbisha. Demonstrative stems are generally used for third person in Central Numic, but third-person

\footnotetext{
10 Variants without $a$ are generally used after stems that end in $a$ or $\dot{t}$, unless the final vowel is part of an absolutive suffix. Variants without $a$ and with $m u$ are in free variation.
} 
TABLE 5

Timbisha Pronouns

\begin{tabular}{|c|c|c|c|}
\hline & SG & $\mathrm{DL}$ & PL \\
\hline \multicolumn{4}{|c|}{ Subjective } \\
\hline $1 \mathrm{EXCL}$ & ni & ni-nku $\sim$ nu-nku ${ }^{a}$ & ni-mmi \\
\hline $1 \mathrm{INCL}$ & & ta-nku & ta-mmi \\
\hline 2 & $\dot{i}$ & mu-nku & mi-mmi \\
\hline 3 COREF & $\mathrm{pi}$ & pi-hi $\sim$ pu- $\eta k u$ & pi-mmi \\
\hline \multicolumn{4}{|c|}{ Objective } \\
\hline $1 \mathrm{EXCL}$ & nia & ni-hi $\sim$ nu-hi & ni-mmi \\
\hline $1 \mathrm{INCL}$ & & ta-hi & ta-mmi \\
\hline 2 & in & mu-hi & mi-mmi \\
\hline 3 COREF & pi-nna & pu-hi & pi-mmi \\
\hline \multicolumn{4}{|c|}{ Possessive } \\
\hline $1 \mathrm{EXCL}$ & nian & ni-hin nu-hin & ni-mmin \\
\hline $1 \mathrm{INCL}$ & & ta-hin & ta-mmin \\
\hline 2 & in & mu-hin & mi-mmin \\
\hline 3 COREF & pi-nnan & pu-hin & pi-mmin \\
\hline
\end{tabular}

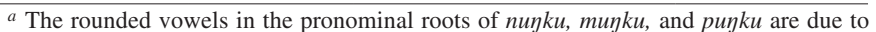
regressive rounding assimilation, a common process in Central Numic, based on the dual subjective suffix. This rounding assimilation is especially common when a monosyllabic morpheme containing either $a$ or $\dot{i}$ precedes a syllable with a rounded vowel. The rounded vowels of the pronominal stems have then been extended into the other cases through analogy. Dayley (1989a:414) calls this vowel harmony, but it more closely resembles assimilation since it is not stem-based as vowel harmony tends to be in languages such as Hungarian. Examples of this assimilation are nakoitsoi $\sim$ nokoitsoi 'bathe, swim' $<$ na- REFL + koitsoi 'wash'; patokoa potokoa 'water snake' < pa- 'water' + tokoa 'snake'; timo' $i \sim$ tumo' $i$ 'write, draw (INTR)' < ti- INDEF OBJ + mo' $i$ 'write, draw (TR)'; kiso'e $\sim$ kuso'e 'bite (PL OBJ)' $<k \dot{t}^{\prime \prime}-$ INTR + -so'e 'pinch (PL OBJ)'.

coreferential pronouns can also be used (except as the subject of the main verb). The demonstrative stems will be illustrated later.

Note in table 5 that the dual is not an expansion of the Proto-Numic dual, which was the first-person-plural inclusive stem. Instead, it is, like the plural, marked by variants of the nominal suffixes, being affixed to the firstperson inclusive and exclusive stems as well as the second- and third-person coreferential stems. It is also declined for case. Note also that the objective suffix is not derived from the subjective suffix in first and second persons. The expected objective suffix $-i$ is not affixed to the subjective form, but to a different morpheme altogether. The possessive in Timbisha is universally formed by affixing - $n$ to the objective form so any comments that apply to the objective forms apply to the possessive as well. Only the third-person coreferential forms show an uncommon subjective suffix variant that served as the archaic basis for the objective and possessive suffixes.

Demonstratives, which serve both as third-person pronouns and demonstrative adjectives, are also marked for dual number. This is illustrated with a proximal 
demonstrative stem in (10). The forms consist of the demonstrative stem si-, the -tin demonstrative suffix, and the same dual suffixes found on the pronouns.

(10) Timbisha

$$
\begin{array}{llll}
\text { 'this, this one' } & \text { SBJ } & \text { SG } & \text { DL } \\
& \text { Si-tin } & \text { si-ti-nku } \sim \text { si-tu-nku } \sim \text { si-ti-hu } \\
& \text { OBJ } & \text { si-kka } & \text { si-ti-hi } \sim \text { si-tu-hi } \\
& \text { POSS } & \text { si-kkan } & \text { si-ti-hin } \sim \text { si-tu-hi } \\
& & \text { PL } \\
& & \text { si-ti-mmi } \\
& \text { si-ti-mmi } \\
& \text { si-ti-mmin }
\end{array}
$$

\begin{tabular}{|c|c|c|c|}
\hline & SG & DL & PL \\
\hline BJ & $-\operatorname{tin}$ & -ti-hi & -ti-mmi \\
\hline BJ & -ti-nna $\sim-$ ti & -ti-hi & -ti-mmi \\
\hline oss & -ti-nnan & -ti-hin & -ti-mmi \\
\hline
\end{tabular}

This set of suffixes is similar to the suffixes used on other nominal modifiers as shown in (11) and illustrated in (12).

(11) Timbisha

(12) Timbisha

$\begin{array}{lll}\text { Wahahtihi }^{11} & \text { pakka } & \text { yuhupi } \\ \text { waha-htihi } & \text { pakka } & \text { yuhu-pi } \\ \text { two-SBJ.DL } & \text { cow } & \text { fat-ABS }\end{array}$

'Two cows are fat.'

(McLaughlin 2006:28)

At the sentence level, Timbisha marks number on imperatives with number enclitics related to the pronominal and demonstrative subjective suffixes as in (13-16). This usage is unique to Timbisha.

(13) Timbisha

Ma yaakki!

3OBJ bring.SG.OBJ

'Bring it!'

Ma yaakki-ujku!

3OBJ bring.SG.OBJ-DL.SBJ

'Bring it, you two!'

Ma yaakki-ummi!

3OBJ bring.SG.OBJ-PL.SBJ

'Bring it, you all!'

(Dayley 1989a:79)

11 The initial consonant of the case and number suffixes on numbers and color adjectives in Eastern Timbisha is usually preaspirated. 
(14) Timbisha

Ma himikki!

3OBJ bring.PL.OBJ

'Bring them!'

Ma himikki-unku!

3OBJ bring.PL.OBJ-DL.SBJ

'Bring them, you two!'

Ma himikki-ummi!

3OBJ bring.PL.OBJ-PL.SBJ

'Bring them, you all!'

(Dayley 1989a:79)

(15) Timbisha

Yitsi!

arise.SG.SBJ

'Get up!'

Yotsi-enku!

arise.PL.SBJ-DL.SBJ

'Get up, you two!'

Yotsi-emmi!

arise.PL.SBJ-PL.SBJ

'Get up, you all!'

(Miller 1965-1968)

(16) Timbisha

$\mathrm{Ti}-$ puni!

INDEF.OBJ-See

'Wake up!'

$\mathrm{Ti}-$ puni-ajku!

INDEF.OBJ-See-DL.SBJ

'Wake up, you two!'

Ti-puni-ammi!

INDEF.OBJ-See-PL.SBJ

'Wake up, you all!'

(Miller 1965-1968)

In Timbisha, two suffixes account for dual marking. The first is the common form used for subjective dual, $-(a) \eta k u$. The uncommon dual objective form $-(V) \eta k w i$ is the subjective $-(V) \eta k u$ plus the objective suffix $-i$. The second is the uncommon form for subjective dual, $-(a) h \dot{t} /-(a) h u$. The common dual objective form $-(a) h i$ is the subjective $-(a) h \dot{i}$ plus the objective suffix $-i$. 
TABLE 6

Central Numic Suppletive Verbs

\begin{tabular}{|c|c|c|c|c|}
\hline & & SG & DL & PL \\
\hline \multicolumn{5}{|c|}{ Dual $=$ Singular, Plural distinct } \\
\hline 'arise, fly' & $\mathrm{Tm}$ & yitsi & yitsi & yoti \\
\hline 'carry, take' & $\mathrm{Tm}$ & yaa & yaa & hima \\
\hline 'die’ & $\mathrm{Tm}$ & tiyai & tiyai & tsiiwa ko’i \\
\hline 'kill' & $\mathrm{Tm}$ & pakka & pakka & wasi \\
\hline \multicolumn{5}{|c|}{ Dual $=$ either Singular or Plural, other number distinct } \\
\hline 'cry' & $\operatorname{Tm}$ & yakai & yakai namo'i & namo'i \\
\hline 'enter' & $\mathrm{Tm}$ & ika & $\mathrm{ika} \sim$ weeki & weeki \\
\hline 'put' & $\mathrm{Tm}$ & tiki & tiki $\sim$ taha & taha \\
\hline 'sleep' & $\mathrm{Tm}$ & ippii & ippii okko'i & okko'i \\
\hline 'wander' & $\mathrm{Tm}$ & nuwi & nuwi $\sim$ nigka & ninka $\sim$ yinka \\
\hline \multicolumn{5}{|c|}{ Dual $=$ Reduplicated Singular, Plural distinct } \\
\hline \multirow[t]{2}{*}{ 'emerge' } & $\mathrm{Tm}$ & to'e & toto'e & kia \\
\hline & $\mathrm{Sh}$ & to'i & toto’i & kia \\
\hline 'enter' & Sh & yua ya'i & yuyua yaya'i & waiku \\
\hline 'fall' & $\mathrm{Sh}$ & pahe $\sim$ pahi & papahi & sawi'i \\
\hline \multirow[t]{2}{*}{ 'run' } & $\operatorname{Tm}$ & nukkwi & nunukkwi & nutaa \\
\hline & Sh & nukki & nunukki & nutaa \\
\hline \multicolumn{5}{|c|}{ Dual $=$ Reduplicated Plural, Singular distinct } \\
\hline 'arise, fly' & Sh & yitsi & yoyoti & yoti \\
\hline 'wander' & Sh & nimi & yiyinka & yinka \\
\hline \multicolumn{5}{|c|}{ Dual = Reduplicated Singular/Plural } \\
\hline \multirow[t]{2}{*}{ 'come' } & $\mathrm{Tm}$ & kimma & kikimma & kimma \\
\hline & $\mathrm{Sh}$ & kimma & kikimma & kimma \\
\hline \multirow[t]{2}{*}{ 'go' } & $\mathrm{Tm}$ & mi’a & mimi'a & mi’a \\
\hline & $\mathrm{Sh}$ & mi’a & mimi'a & mi’a \\
\hline \multirow[t]{2}{*}{ 'return’ } & $\mathrm{Tm}$ & ko'e $\sim$ kohi & koko'e & ko'e \\
\hline & $\mathrm{Sh}$ & ko’i & koko'i & ko’i \\
\hline
\end{tabular}

In addition to nominal, pronominal, and nominal modifier marking, dual has also made some inroads into the number suppletion found on many common verbs in Timbisha and Shoshoni (but not Comanche). Table 6 provides a representative list. Note that some verbs use the singular form for dual, some have a distinct form for dual that contrasts with a common singular-plural form, and a small number have three-way suppletion. There is wide variation among speakers and between dialects in some forms. ${ }^{12}$ Number suppletion in

12 Since the complexity of forms for dual verb suppletion falls outside the main scope of this paper, the only forms shown here are from Dayley (1989b) (Tm); Crum, Crum, and Dayley (2001) (Sh) (principally Owyhee, near the center of the Shoshoni range); and Canonge (1958) $(\mathrm{Cm})$. All the selected singular forms and most of the plural and dual forms are cognate. This is a comprehensive list, but not a complete one. 
TABLE 6-continued

\begin{tabular}{|c|c|c|c|c|}
\hline \multicolumn{5}{|c|}{ Dual $=$ Historic Plural, Singular and Plural distinct } \\
\hline 'sit' & $\mathrm{Tm}$ & kati & yikwi & nuupai $\sim$ yuunaa $\sim$ yinka \\
\hline \multicolumn{5}{|c|}{ Timbisha and Shoshoni Forms with no Dual ${ }^{a}$} \\
\hline 'carry, take' & Sh & yaa & hima & hima \\
\hline 'cry' & $\mathrm{Sh}$ & yakai & nawoi & nawoi \\
\hline 'die’ & Sh & tiyai & koi & koi \\
\hline 'fall' & $\operatorname{Tm}$ & pahe & pokoa & pokoa \\
\hline 'kill' & $\mathrm{Sh}$ & pekka & wasi & wasi \\
\hline 'put' & Sh & tiki & tahna & tahna \\
\hline 'sit' & $\mathrm{Sh}$ & kati & yikwi & yikwi \\
\hline 'sleep' & $\mathrm{Sh}$ & ippii & ikkoi & ikkoi \\
\hline \multicolumn{5}{|c|}{ Comanche Forms } \\
\hline 'arise, fly' & $\mathrm{Cm}$ & yitsi & yori & yori \\
\hline 'carry, take' & $\mathrm{Cm}$ & уаа & hima & hima \\
\hline 'come' & $\mathrm{Cm}$ & kima & kima & kima \\
\hline ‘cry' & $\mathrm{Cm}$ & yake & nahwooi & nahwooi \\
\hline 'die' & $\mathrm{Cm}$ & tiyaai & kooi & kooi \\
\hline 'emerge' & $\mathrm{Cm}$ & to' $\mathrm{i}$ & kia & kia \\
\hline 'enter' & $\mathrm{Cm}$ & ika & wekwi & wekwi \\
\hline 'fall' & $\mathrm{Cm}$ & pahi & yuma & yuma \\
\hline 'go' & $\mathrm{Cm}$ & mi'a & mi’a & mi’a \\
\hline 'kill' & $\mathrm{Cm}$ & pehka & wasi & wasi \\
\hline 'put' & $\mathrm{Cm}$ & tiki & tahni'i & tahni'i \\
\hline 'return' & $\mathrm{Cm}$ & ko'i & koyama & koyama \\
\hline 'run' & $\mathrm{Cm}$ & nuhki & nuraa & nuraa \\
\hline 'sit' & $\mathrm{Cm}$ & kari & yikwi & yikwi \\
\hline 'sleep' & $\mathrm{Cm}$ & ihpii & ihkooi & ihkooi \\
\hline ‘wander' & $\mathrm{Cm}$ & nimi & yika & yika \\
\hline
\end{tabular}

${ }^{a}$ In these forms the other language (Tm and $\mathrm{Sh}$ ) does have separate dual marking.

Central Numic verbs is ergative- that is, suppletive forms for transitive verbs mark the number of the object whereas suppletive forms for intransitive mark the number of the subject. The fact that number suppletion in verbs is not found in Comanche indicates that this is a relatively recent development in Shoshoni and Timbisha and is spreading from west to east. The easternmost Shoshoni dialect in Wyoming has fewer dual suppletive forms than the western dialects in Nevada. ${ }^{13}$ This supports the known historical development of Shoshoni dialects wherein Comanche (with no dual suppletive forms) split

13 Based on the number of suppletive forms found in the various descriptions and dictionaries of Shoshoni (McLaughlin 2015). Note even here in this limited data set that there are more forms with no separate dual for Shoshoni than there are for Timbisha. From west to east the principal dictionaries and descriptions are Crapo (1976) (southwest Nevada), Crum and Dayley (1993) (northern Nevada), Miller (1972, 1996) (Nevada-Utah border), Gould and Loether (2002) (Idaho), and Shaul (2012) (Wyoming). McLaughlin (2012) is generalized and not based on a specific dialect. 
from the easternmost Shoshoni dialect in late precontact times, possibly as late as the beginning of the eighteenth century (McLaughlin 2000).

At this point it should be clear that dual marking in Central Numic has expanded to include many more realms than those hinted at in either Western Numic or Southern Numic, and that it has achieved a nearly equal status with singular and plural, especially within the paradigms of nominal, pronominal, and nominal modifier affixation.

6. Number in Shoshoni. Shoshoni adds more complexity to the issue since the subjective dual suffix is not related to the Timbisha form and the possessive dual suffix is more commonly based on the archaic subjective suffix and not the inflected objective suffix. In addition, the nominal number suffixes are complex and will be discussed after the other paradigms. As in Timbisha, there are also some uncommon variants within the paradigms.

The Shoshoni pronouns are shown in table 7. Three things should be noted about this set when comparing the dual forms to the Timbisha set in table 5. First, the common objective dual form endings are identical; second, the subjective and possessive dual form endings are different; and third, the vowel assimilation in the pronominal roots of the Timbisha dual is absent in Shoshoni. This pattern holds true for Shoshoni suffixes on demonstratives, animate interrogative/ indefinite pronouns, and adjectives, all based on the subjective singular suffix -tin, as shown in (17-19). Non-singular adjectives are also often reduplicated.

(17) Shoshoni

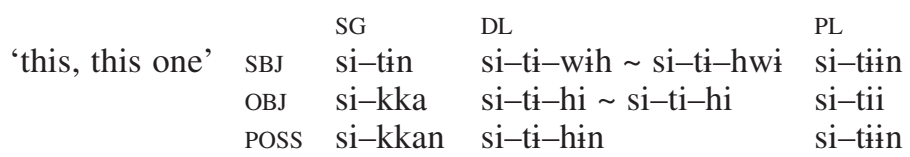

(18) Shoshoni ${ }^{14}$

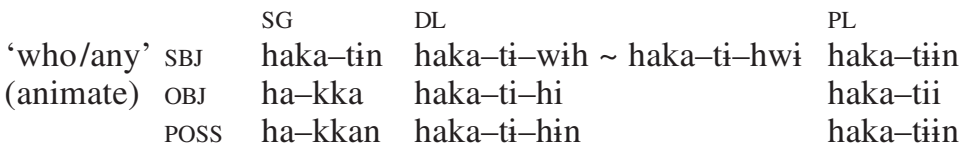

14 This system of interrogative/indefinite pronouns has been borrowed into Eastern Timbisha (McLaughlin 2006). The non-singular number and case suffixes, however, are not from Shoshoni, but are based on the Timbisha number suffixes - $t \dot{t}-\eta k u$ (dual) and -ti-mmi (plural) with the objective suffix $-i$ and the possessive suffix $-n$ added to the objective form in analogy with the case and number suffix system of the demonstratives. This leads to the uncommon Timbisha objective dual - $\eta k w i$ (possessive - $\eta k w i n)$.

(ii) Timbisha

$\begin{array}{lllll}\text { 'what/any' } & & \text { SG } & \text { DL } & \text { PL } \\ & \text { SBJ } & \text { haka-tin } & \text { haka-ti-nku } & \text { haka-ti-mmi } \\ & \text { OBJ } & \text { ha-kka } & \text { haka-ti-nkwi } & \text { haka-ti-mmi } \\ & \text { POSS } & \text { ha-kkan } & \text { haka-ti-nkwin } & \text { haka-ti-mmin }\end{array}$


TABLE 7

Shoshoni Pronouns

\begin{tabular}{|c|c|c|c|}
\hline & SG & DU & PL \\
\hline \multicolumn{4}{|c|}{ Subjective } \\
\hline 1 EXCL & $\mathrm{ni}$ & ni-wih $\sim$ ni-hwi ${ }^{a}$ & ni-mmin \\
\hline $1 \mathrm{INCL}$ & & ta-wih ta-hwi & ta-mmin \\
\hline 2 & in & mi-wih mi-hwi & mi-mmin \\
\hline 3 COREF & pin $\sim$ pin-nin & pi-wih pi-hwi & pi-mmin \\
\hline \multicolumn{4}{|c|}{ Objective } \\
\hline 1 EXCL & nii & ni-hi $\sim$ ni-hii & ni-mmi \\
\hline $1 \mathrm{INCL}$ & & ta-hi ta-hai & ta-mmi $\sim$ tai \\
\hline 2 & in $\sim \mathrm{i}-\mathrm{mmi}$ & mi-hi mi-hii & mi-mmi mii \\
\hline 3 COREF & pii pi-nni & pi-hi pi-hii & pi-mmi \\
\hline \multicolumn{4}{|c|}{ Possessive } \\
\hline 1 EXCL & ni $\sim$ ni-an & ni-hin ni-hin & ni-mmin \\
\hline $1 \mathrm{INCL}$ & & ta-han ta-hain & ta-mmin \\
\hline 2 & in $\sim$ i-mmin & mi-hin mi-hin & mi-mmin \\
\hline 3 COREF & pin $~$ pi-nnan & pi-hin pi-hin & pi-mmin \\
\hline \multicolumn{4}{|c|}{$\begin{array}{l}\text { 'a In Northern Shoshoni and Eastern Shoshoni (Gould and Loether 2002; Tid- } \\
\text { zump 1970; Shaul 2012; Dayley 1970), the dual subjective forms end in - } h w i \text {. This } \\
\text { is the result of a metathesis (also found in Comanche) of /RVhV/ to [hRV], where } \\
\text { V is an unstressed vowel and R is } r \text { (Comanche only) or a glide. This occurs in } \\
\text { other forms, for example, puhi 'leaf' + wihi 'metal' > puihwi (Eastern Shoshoni) / } \\
\text { puhihwi (Comanche) 'money'. Crapo's description of Duckwater Shoshoni (1970) } \\
\text { lists the dual subjective suffixes as -wih, but his dictionary of Big Smokey Valley } \\
\text { Shoshoni (1976) lists them as - } h w i h \text {. Some of this variation is the result of dif- } \\
\text { ferent transcription practices, some is the result of dialect variation, and some is } \\
\text { the result of the complex history of vowel devoicing and linguistic acculturation } \\
\text { in Shoshoni. None of the variation affects the arguments for the history of dual } \\
\text { marking presented here, however. }\end{array}$} \\
\hline
\end{tabular}

(19) Shoshoni ${ }^{15}$

$$
\begin{array}{lllll} 
& & \text { SG } & \text { DL } & \text { PL } \\
\text { 'little' } & \text { SBJ } & \text { tii-tin } & \text { (ti)tii-ti-wih } \sim(\text { ti)tii-ti-hwi } & \text { (ti)tii-tiin } \\
& \text { OBJ } & \text { tii-ti } & \text { (ti)tii-ti-hi } & \text { (ti)tii-tii }
\end{array}
$$

In addition to having a different set of subjective dual pronominal affixes, Shoshoni has a different set of nominal suffixes, as shown in (20), which are also used on the inanimate interrogative/indefinite pronouns in (21). The Shoshoni dual set includes a non-singular suffix -ni in front of the dual number suffixes.

15 Examples of adjectives modifying possessive nominals are very rare, and no generalizations about their affixes can be made at this time. Adjective forms based on -tin sometimes vary between the regular -tin set and a -ntin set with an initial $n$. This variation is unpredictable and can be individual or dialectal. The -ntin set is not mentioned here further as it is unrelated to the expansion of dual marking in Central Numic. 
(20) Shoshoni

$\begin{array}{lll} & \text { DL } & \text { PL } \\ \text { SBJ } & \text {-ni-wih } & \text {-niin } \\ \text { OBJ } & \text {-ni-hi } & \text {-nii } \\ \text { POSS } & \text {-ni-hin } & \text {-niin }\end{array}$

(21) Shoshoni

$$
\begin{array}{lllll} 
& & \text { SG } & \text { DL } & \text { PL } \\
\text { 'what/any' } & \text { SBJ } & \text { hiin } ~ \text { hinni } & \text { hiin-ni-wih } & \text { hiin-niin } \\
\text { (inanimate) } & \text { OBJ } & \text { hi-nna } & \text { hiin-ni-hi } & \text { hiin-nii } \\
& \text { POSS } & \text { hi-nnan } ~ \text { hi-nnin } & \text { hiin-ni-hin } & \text { hiin-niin }
\end{array}
$$

The basic Shoshoni dual affixes therefore are $-w i t h(\sim-h w i)$ for subjective, - $h i$ for objective, and - hin for possessive. Used on nominals and inanimate interrogative/indefinite pronouns, the basic suffixes are preceded by $-n \dot{i} .^{16}$ Used on demonstratives, animate interrogative/indefinite pronouns, and adjectives, the basic suffixes are preceded by $-t \dot{t}$. The Shoshoni suffixes are compared with the Timbisha suffixes in (22).

$$
\begin{array}{llll} 
& \text { SBJ } & \text { OBJ } & \text { POSS } \\
\text { Timbisha } & -\eta \mathrm{ku} \sim-\text { hi } & - \text { hi } & - \text { hin } \\
\text { Shoshoni } & - \text { wih }(\sim-\text {-hwi }) & \text {-hi } & \text {-hin }(\sim-\text { hin })
\end{array}
$$

At the sentence level, unlike Timbisha, Shoshoni occasionally exhibits the use of the basic dual suffix on a verb to mark dual number. This is an uncommon usage and sometimes marks the subject of a transitive verb, as in (23), and sometimes the number of the object, as in (24).

(23) Shoshoni

So-tiwih nanakkwihi-nniwih tipitsi tsaam pi-hin DEM-DL.SBJ married.couple-DL.SBJ very good COREF-DL.POSS

$$
\begin{array}{ll}
\text { tu-tua-ttsi-nii } & \text { manapui-hti-wih } \\
\text { RDP-child-DIM-PL.OBJ } & \text { look.after-PRES-DL(SBJ) }
\end{array}
$$

'That couple takes very good care of their children.'

(Crum and Dayley 1993:166)

(24) Shoshoni

Sa-ti wihyu u-tihi mianki-nu-wih

DEM-SG.SBJ then DEM-DL.OBJ chase-PAST-DL.OBJ

'She was chasing those two.'

(Miller 1972:40)

This usage is rare in the extant documentation and probably indicates an incipient grammaticalization of an enclitic coreferential pronoun that repeats the number of the verb subject, as in (25).

${ }^{16}$ The $-n i$ in the objective is the result of vowel assimilation with the following $-h i$. 
TABLE 8

Comanche Pronouns

\begin{tabular}{|c|c|c|c|}
\hline & SG & DU & PL \\
\hline \multicolumn{4}{|c|}{ Subjective } \\
\hline $1 \mathrm{EXCL}$ & ni' $\sim$ nì & ni-kwih & ni-nni \\
\hline 1 INCL & & ta-hih $\sim$ ta-kwih & ta-nni \\
\hline 2 & inni & mi-hih mi-kwih & mi-nni $\sim$ mi-mmi \\
\hline 3 COREF & pinni & pi-hih pi-kwih & pi-mmi \\
\hline \multicolumn{4}{|c|}{ Objective } \\
\hline $1 \mathrm{EXCL}$ & $\mathrm{ni} \sim$ nie $\sim$ nie-ti & ni-hi & ni-mmi \\
\hline $1 \mathrm{INCL}$ & & ta-hi & tai $\sim$ ta-mmi \\
\hline 2 & $\dot{\mathrm{i}} \sim \mathrm{i}-\mathrm{mmi} \sim \mathrm{i}-\mathrm{mmi}$ & mi-hi & $\mathrm{mii} \sim \mathrm{mi}-\mathrm{mmi}$ \\
\hline 3 COREF & $\mathrm{pi} \sim \mathrm{pi}-\mathrm{mmi}$ & pi-hi & pii $\sim$ pi-mmi \\
\hline \multicolumn{4}{|c|}{ Possessive } \\
\hline $1 \mathrm{EXCL}$ & ni & ni-hi= & ni-mmi $=$ \\
\hline $1 \mathrm{INCL}$ & & $\mathrm{ta}^{-} \mathrm{hi}=\sim$ ta-ha $=\sim \mathrm{taa}=$ & $\mathrm{taa}^{=} \sim$ ta-mmi $=\sim \mathrm{tai}^{-}$ \\
\hline 2 & $\mathrm{i}^{=}$ & mi-hi= & $\mathrm{mit}^{=} \sim \mathrm{mi}-\mathrm{mmi}^{\prime}$ \\
\hline 3 COREF & $\mathrm{pi}=\sim \mathrm{pi}-\mathrm{mmi}=$ & pi-hi $=$ & $\mathrm{pii}=\sim \mathrm{pi}-\mathrm{mmi}^{\prime}$ \\
\hline
\end{tabular}

(25) Shoshoni

Su-tiwih tiasi witan tu-tua-niwih ti-tiai-tiwih DEM-DL.SBJ also bear RDP-child-DL.SBJ RDP-little-DL.SBJ

nikakkin-na=piwih.

dance.DUR-PRES $=$ COREF.DL.SBJ

'Those two little bear cubs were also dancing.'

(Miller 1972:78)

7. Number in Comanche. Since Comanche has separated from Shoshoni relatively recently, it would be expected that the Comanche system of dual marking might mirror the Shoshoni system fairly closely, if not be nearly identical to it. This, however, is not the case. The Comanche pronouns are shown in table $8 .{ }^{17}$

Although the objective forms of the dual are identical to the Shoshoni and Timbisha forms, and the possessive forms of the dual are generally identical

17 The Comanche grammar descriptions and unmarked examples are from Charney (1993) and Robinson and Armagost (1990). The symbol at the end of morphemes in Comanche is a morphophonemic marker that is cognate with morpheme-final $n$ in Shoshoni. It has no phonetic value itself, but it blocks the lenition of a following $p$ or $t$. The $H$ represents preaspiration of a stop. $H C$ in Comanche, where $C$ is a voiceless stop or affricate, is cognate with $C C$ in Shoshoni. Although $H$ is phonetically identical with $h$ after a stressed vowel, it is phonologically distinct and does not regularly trigger the devoicing of a preceding unstressed vowel. 
to the Shoshoni forms, the subjective forms differ from both Shoshoni and Timbisha. Of the two subjective forms, the one with $h$ rather than $k w$ is more common in the older data from the nineteenth and early twentieth centuries, whereas the forms with $k w$ have completely supplanted those with $h$ in contemporary Comanche. This variation between $h$ and $k w$ in Comanche subjective forms is repeated in all other dual marking in Comanche, including the demonstratives in (26) and the nominal suffixes in (27).

Comanche

$\begin{array}{lllll} & & \text { SG } & \text { DL } & \text { PL } \\ \text { 'this, this one'18 } & \text { SBJ } & \text { si-ti }= & \text { si-ti-hih } \sim \text { si-ti-kwih } & \text { si-tii }= \\ & \text { OBJ } & \text { si-Hka } & \text { si-ti-hi } \sim \text { si-ti-hi } & \text { si-tii } \\ & \text { POSS } & \text { si-Hka }= & \text { si-ti-hi }= & \text { si-tii }=\end{array}$

(27) Comanche

\begin{tabular}{|c|c|}
\hline & DL \\
\hline & -ni-kwih \\
\hline & -ni-hi ni-kwiha \\
\hline OSS & $-\mathrm{ni}-\mathrm{hi}=\sim$ nikwi $=\sim$ \\
\hline
\end{tabular}

Whereas the objective dual form with $h$ matches the form found in Shoshoni, and has the objective suffix $-i$, the objective dual form with $k w$ is unique to Comanche and has the objective suffix $-a$, which is the usual objective suffix for nouns that end in $h$, as in haitsih 'friend', haitsiha 'friend (OBJ)'. The possessive forms in Comanche also show both the older and regular Shoshoni forms with $h$ and the Comanche innovative forms with $k w$.

8. Reconstructing Central Numic. In (28) the various common suffix forms from the three languages are presented for comparison.

\begin{tabular}{|c|c|c|c|c|}
\hline \multirow[t]{2}{*}{ pronoun, etc. } & SBJ & $\begin{array}{l}\text { Timbisha } \\
-\eta k u \sim-h u / i\end{array}$ & $\begin{array}{l}\text { Shoshoni } \\
\text {-wih }\end{array}$ & $\begin{array}{l}\text { Comanche } \\
\text {-hih } \sim-\text { kwih }\end{array}$ \\
\hline & OBJ & & -hi & -hi \\
\hline \multirow{4}{*}{ ioun } & POSS & -hin & -hin & $-h \mathrm{i}=$ \\
\hline & SBJ & -ayku $\sim$-hu & -ni-wih & -ni-hih ni-kwih \\
\hline & OBJ & -ahi & -ni-hi & -ni-hi ni-kwiha \\
\hline & POSS & -ahin & -ni-hin & $\begin{array}{c}- \text { nihi }^{=} \sim \text { ni-kwi }=\sim \\
\text { ni-kwiha }=\end{array}$ \\
\hline
\end{tabular}

It is clear that all three languages have different forms for dual subject, but the remainder of the paradigm is fairly consistent across the three languages when the older Comanche forms with $-h$ are considered rather than the newer

\footnotetext{
18 The demonstrative stems with back vowels $\left[(s) u-,(s) o_{-}\right.$, and $\left.m a-\right]$ also undergo the metathesis of $/ \mathrm{RVhV} />/ \mathrm{hRV} /$ described above, so the dual objective of ma- is mahri and the dual possessive mahri ${ }^{=}$.

${ }^{19}$ Charney (1993) notes that the $-k w$ forms are preferred for humans.
} 
innovations with $-k w$. When deciding what to reconstruct for Proto-Central Numic, it seems clear that the oblique system is reconstructible and was based on a subjective form that started with $-h$. Since both Timbisha and Comanche have a variant subjective form that begins with $-h$, then a Proto-Central Numic subjective dual $*$ - $h \dot{t}$ can be reconstructed.

The Proto-Central Numic object form, which is still found in all three daughter languages, was therefore $*$-hi, which is the result of adding the objective suffix $*_{-} i$ to the subjective form $*_{-} h \dot{t}$ with regular vowel coalescence of $\dot{t}$ and $i$. The possessive forms in Shoshoni and Comanche also represent the reflex of Proto-Central Numic $*$ - $h \dot{t}$ with the possessive suffix $-n$ affixed. This is exceptional, however, since the Numic languages otherwise uniformly use objective forms as the base for marking possessive relationships. ${ }^{20}$

Since the Central Numic dual system cannot be derived from the rudimentary Proto-Numic system described above, we must search for a possible source for Proto-Central Numic *-hi. When searching for a source for a dual affix, the most logical place to begin is the numeral two (Heine and Kuteva 2002:302-3). In Proto-Central Numic, the numeral two was *waha, and this seems to be the source for the earliest grammaticalization for dual along a route of development illustrated in (29).

(29) Proto-Central Numic

*waha 'two' > *-waha as dual suffix

$>*_{-} h a$, by loss of intervocalic $*_{w}$ and unstressed $a^{21}$

$>*_{-} h \dot{t}$, by vowel assimilation with $*_{n i}$ - first person and $* m i$ - second person pronominal roots

$>*_{-} h i$, by affixing objective suffix $*_{-} i$ and coalescing final vowels

Whereas all the daughters retained the objective and possessive forms of the suffix, only older Comanche retained the original subjective suffix $*$ - $h \dot{t}$ as the most common form. In Timbisha, the archaic suffix has also been retained as an uncommon option in some subjective paradigms, such as coreferential pronoun pihi $\sim$ puyku, nominal suffix -ahu, demonstrative sitijku $\sim$ situyku

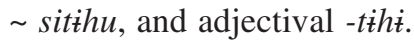

9. Development in Timbisha. In the single development in Timbisha, shown in (30), a grammaticalization of some presently unidentified element yielded the subjective dual $-\eta k u$ that has generally replaced the Proto-Central Numic *-hi.

\footnotetext{
${ }^{20}$ The development of possessive marking in the Numic languages is complex and beyond the scope of this paper.

21 The loss of intervocalic ${ }^{*} w$ in Central Numic is independently motivated as in Proto-Central Numic *awa 'horn' > Timbisha awa, Shoshoni aa, Comanche aa.
} 
TABLE 9

Numic INTERVOCALIC LENITION OF $*_{m}$

\begin{tabular}{lllll}
\hline \hline & 'lungs' & 'carry' & 'wander' & 'horn' \\
\hline PN & *somo & *yami & & \\
PCN & *somo & *yaa & *nimi & *ama" \\
Mono & sono & & niwi & awa \\
Northern Paiute & sono & yawi & nimi & aa \\
Kawaiisu & soo & yaa & & $\mathrm{aa}^{\prime \prime}$ \\
Colorado River & soo & yaa/yanwi & & $\mathrm{aa}^{\prime \prime}$ \\
Timbisha & somo/sonwo & yaa & nuwi & ama"/awa" \\
Shoshoni & sonno/sonko & yaa & nimi & aan \\
Comanche & soomo & yaa & nimi & aa \\
\hline
\end{tabular}

(30) Timbisha

$*_{-} h \dot{t}$, dual subjective replaced by $-\eta k u$

By analogy, the objective $-\eta k w i$ and possessive $-\eta k w i n$ have developed from subjective $-\eta k u$ in some paradigms. ${ }^{22}$

10. Developments in Shoshoni and Comanche. The first item we'll account for in Shoshoni and Comanche is the - $n \dot{i}$ found as part of the nominal number suffixes in both languages. Since this suffix is found on both dual and plural suffixes, several candidates for grammaticalization can be investigated. In Timbisha, some human nouns can be pluralized by the affixation of the noun nimi 'person' following the stem (Dayley 1989a:218). This is shown in (31).

(31) Timbisha

$$
\begin{array}{lll} 
& \text { SG } & \text { PL } \\
\text { 'older sister' } & \text { patsi } & \text { patsi-nimi } \\
\text { 'cousin' } & \text { pia } & \text { pia-nimi }
\end{array}
$$

(Dayley 1989a:218)

When we compare this with the Shoshoni number suffixes, the similarities to the first syllable of the forms affixed to Timbisha nominals become readily

22 The basic underlying morpheme structure in Central Numic is $C V\left(N /{ }^{\prime \prime} / H\right) C V\left(N /{ }^{\prime \prime} / H\right)$, where $C$ is any consonant or no consonant, $V$ is any vowel, long or short, monophthong or diphthong, $N$ is any nasal consonant, $H$ is any glottal, and "geminates any following consonant except $H$. Thus the choice of final segment for innovative dual suffix in Timbisha is between - $\eta k u$, which follows the morpheme structure constraints, and $*_{-}-\eta k w$, which does not. Whenever a morpheme ends in $k u$ or $h u$ in Timbisha, the addition of the objective suffix $-i$ yields [kwi] and [hwi],

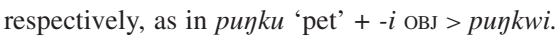


apparent. The loss of intervocalic $m$ is a common feature not only in Central Numic and Numic, but throughout Uto-Aztecan. Examples from Numic are shown in table 9.

A generalized schematic of the sequence of changes from $m$ to $\emptyset$ is shown in (32).

(32) $\mathrm{m}>$ jw $>\tilde{\mathrm{w}}>\mathrm{w}>\emptyset^{23}$

We can thus track the reduction of nimi in Pre-Shoshoni to the -nit that precedes the number suffixes in Shoshoni and Comanche in (33).

(33) Shoshoni-Comanche

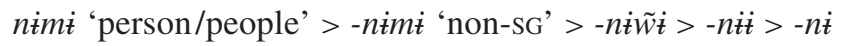

Thus, the Shoshoni and Comanche -ni syllable that precedes the non-singular number suffixes is a grammaticalized form of nimi 'person'. Its grammaticalization and merger with the non-singular number suffixes occurred after the split between Timbisha and Shoshoni.

In Shoshoni, a second grammatalization of *waha 'two' replaced the earlier *-hi subjective form as shown in (34). This time, however, rather than losing the first syllable to reduction, the final syllable was lost with the same vowel harmony as before. Although all contemporary dialects of Shoshoni show this change, it was only beginning to affect Comanche when it broke off in the early eighteenth century.

(34) Shoshoni

- $h \dot{t}$, DL.SBJ replaced by second grammaticalization of waha, 'two' > - waha $>-w a h>-w i h(>-h w \dot{t})$

Finally, in Comanche, as shown in (35), there is an irregular, but not uncommon, process whereby a $w$ at a morpheme boundary can become strengthened to $g w$. Before a voiceless vowel (as at the end of $-w i t h$ ), this $g w$ is devoiced to $[\mathrm{kw}]$. Thus, we end with the modern Comanche form - $k w i$ for dual subjective, which has completely replaced the older Proto-Central Numic form for dual subjective as shown in (36).

(35) Comanche

tsi- 'with a sharp point' + -wai 'poke' $>$ [tsigwai] 'poke with a stick' $s u$ - 'with the mind' + -wai 'poke' $>$ [sugwai] 'want'

$n \dot{t}$ 'my' + wosa 'bag' > [nigwosa] 'purse'

pasa 'sand' + wiyo 'frog' > [pasagwiyo] or [pasawiyo] 'frog sp.'

(36) Comanche

$-w i h h[-\mathrm{gwf}]>[-\mathrm{kwf}]>-k w \dot{t} h$, dual subjective

23 This sequence is not absolute and there is some variation. Langacker (1977:23) breaks it into two sequences, $* m>\tilde{w}>w$ and $* m>\tilde{w}>\eta w>\eta(>n)$. 
11. Summary. The listing in (37) illustrates the overall process by which the various dual affixes were grammaticalized in Central Numic, including four separate grammaticalization events, twice with 'two', once with 'person', and once with a presently unknown element. Central Numic is thus a good example of how a rudimentary indication of dual number can be expanded to fill most, if not all, appropriate slots in a nonverbal paradigm.

(37) Central Numic

\begin{tabular}{|c|c|c|}
\hline Proto-Central Numic & *waha 'two' & $>*_{-} h \dot{t}$ DL SBJ, $*_{-} h i$ DL OBJ \\
\hline Timbisha & ? & $>-\eta k u$, replacing $-* h \dot{t}$ DL SBJ \\
\hline Shoshoni-Comanche & nimi 'person' & $>\quad-n \dot{t}-h \dot{t}$ DL SBJ, $-n \dot{t}-h i$ DL OBJ \\
\hline Shoshoni & waha 'two' & $>\quad-w \dot{h}$, replacing -hit DL SBJ \\
\hline Comanche & $-w i h$ & $\begin{array}{c}>-k w i h, \text { recently replacing } \\
-h i h \text { DL SBJ }\end{array}$ \\
\hline
\end{tabular}

\section{REFERENCES}

Babel, Molly, Andrew Garrett, Michael J. Houser, and Maziar Toosarvandani. 2013. Descent and diffusion in language diversification: A study of Western Numic dialectology. IJAL 79:445-89.

Canonge, Elliott. 1958. Comanche Texts. Summer Institute of Linguistics Publications in Linguistics No. 1. Norman, OK: Summer Institute of Linguistics.

Charney, Jean O. 1993. A Grammar of Comanche. Studies in the Anthropology of North American Indians. Lincoln: University of Nebraska Press.

Crapo, Richley H. 1970. Language variation among the Duckwater Shoshoni. PhD dissertation, University of Utah.

. 1976. Big Smokey Valley Shoshoni. Desert Research Institute Publications in the Social Sciences No. 10. Reno: Desert Research Institute.

Crum, Beverly, Earl Crum, and Jon P. Dayley. 2001. Newe Hupia: Shoshoni Poetry Songs. Logan: Utah State University Press.

Crum, Beverly, and Jon Dayley. 1993. Western Shoshoni Grammar. Boise State University Occasional Papers and Monographs in Cultural Anthropology and Linguistics Vol. 1. Boise: Department of Anthropology, Boise State University.

Cysouw, Michael. 2013. Inclusive/exclusive distinction in independent pronouns. The World Atlas of Language Structures Online, ed. Matthew S. Dryer and Martin Haspelmath. Leipzig: Max Planck Institute for Evolutionary Anthropology. <http://wals.info/chapter/39>.

DAYLEY, Jon Philip. 1970. Shoshone phonology and morpohological sketch. MA thesis, Idaho State University.

. 1989a. Tümpisa (Panamint) Shoshone Grammar. University of California Publications in Linguistics Vol. 115. Berkeley: University of California Press.

. 1989b. Tümpisa (Panamint) Shoshone Dictionary. University of California Publications in Linguistics Vol. 116. Berkeley: University of California Press.

Givón, Talmy. 2011. Ute Reference Grammar. Culture and Language Use, Vol. 3. Amsterdam: John Benjamins.

Gould, Drusilla, And Christopher Loether. 2002. An Introduction to the Shoshoni Language: Dammen Daigwape. Salt Lake City: University of Utah Press.

Heine, Bernd, and Tania Kuteva. 2002. World Lexicon of Grammaticalization. Cambridge: Cambridge University Press. 
Hopi Dictionary Project, THE. 1998. Hopi Dictionary, Hopìikwa Lavàytutuveni, A Hopi-English Dictionary of the Third Mesa Dialect, with an English-Hopi Finder List and a Sketch of Hopi Grammar. Tucson: University of Arizona Press.

Jeanne, Laverne Masayesva. 1978. Aspects of Hopi grammar. PhD dissertation, Massachusetts Institute of Technology.

Langacker, Ronald W. 1977. Studies in Uto-Aztecan Grammar, Vol. 1: An Overview of UtoAztecan Grammar. Summer Institute of Linguistics Publications in Linguistics 56. Dallas: Summer Institute of Linguistics and University of Texas at Arlington.

McLaughlin, John E. 2000. Language boundaries and phonological borrowing in the Central Numic languages. Uto-Aztecan: Structural, Temporal, and Geographic Perspectives, Papers in Memory of Wick R. Miller by the Friends of Uto-Aztecan, ed. Eugene H. Casad and Thomas L. Willet, 293-303. Hermosillo, Mexico: Universidad de Sonora, Division de Humanidades y Bellas Artes.

. 2006. Timbisha (Panamint). Languages of the World/Materials 453. Munich: LINCOM Europa.

— 2012. Shoshoni Grammar. Languages of the World/Materials 488. Munich: LINCOM Europa.

- 2015. Northern Uto-Aztecan: Sprachbund, diffusion, or inheritance? Paper presented at Society for the Study of the Indigenous Languages of the Americas, Portland, Oregon.

Miller, Wick R. 1965-1968. Fieldnotes on Timbisha, photocopies in author's possession. Originals housed at Marriott Library, University of Utah.

- 1972. Newe Natekwinappeh: Shoshoni Stories and Dictionary. University of Utah Anthropological Papers No. 94. Salt Lake City: University of Utah Press.

. 1996. Sketch of Shoshone, a Uto-Aztecan language. Handbook of North American Indians, Vol. 17, Languages, ed. Ives Goddard, 693-720. Washington, DC: Smithsonian Institution.

NorRis, Evan J. 1986. A grammar sketch and comparative study of Eastern Mono. PhD dissertation, University of California, San Diego.

Press, Margaret L. 1980. Chemehuevi, a Grammar and Lexicon. University of California Publications in Linguistics Vol. 92. Berkeley: University of California Press.

Robinson, Lila Wistrand, and James Armagost. 1990. Comanche Dictionary and Grammar. Summer Institute of Linguistics and University of Texas at Arlington Publications in Linguistics 92. Dallas: Summer Institute of Linguistics and University of Texas at Arlington.

SAPIR, EDWARD. 1930. Southern Paiute, a Shoshonean Language. Reprinted 1992 in The Collected Works of Edward Sapir X: Southern Paiute and Ute Linguistics and Ethnography, ed. William Bright, 17-314. Berlin: Mouton deGruyter.

Shaul, David L. 2012. Eastern Shoshone Working Dictionary. <http://www.wyominglinguistics. org/2012/09/06/eastern-shoshone-working-dictionary-3/>.

Snapp, Allen, John Anderson, And Joy Anderson. 1982. Northern Paiute. Studies in Uto-Aztecan Grammar, Vol. 3: Uto-Aztecan Grammatical Sketches, ed. Ronald W. Langacker, 1-92. Summer Institute of Linguistics Publications in Linguistics No. 57, Vol. III. Dallas: Summer Institute of Linguistics and University of Texas at Arlington.

Thornes, Tiмотну John. 2003. A Northern Paiute grammar with texts. PhD dissertation, University of Oregon.

Tidzump, Malinda. 1970. Shoshone Thesaurus. Grand Forks, ND: Summer Institute of Linguistics and University of North Dakota.

Voegelin, Charles F. 1935. Tübatulabal grammar. University of California Publications in American Archaeology and Ethnology 34(2):55-190.

Zigmond, Maurice L., Curtis G. Booth, and Pamela Munro. 1991. Kawaiisu, a Grammar and Dictionary with Texts, ed. Pamela Munro. University of California Publications in Linguistics Vol. 119. Berkeley: University of California Press. 